THE EUROPEAN JOURNAL OF LIFE WRITING VOLUME VIII (2019)R1-R7

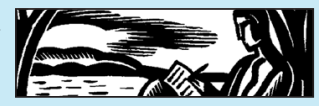

\title{
Anne Frank tout entière ${ }^{1}$
}

\section{Philippe Lejeune}

Anne Frank, L'Intégrale, édité sous les auspices de l'Anne Frank Fonds, Bâle, traduit du néerlandais par Philippe Noble et Isabelle Rosselin (Paris: Calmann-Lévy, 2017, 805 pp., ISBN 978-2702161722)

Ari Folman, David Polonsky, Le Journal d'Anne Frank, traduit de l'anglais par Claire Desserrey et du néerlandais par Isabelle Rosselin et Philippe Noble (Paris: Calmann-Lévy, 2017, 153 pp., ISBN 978-2702160930)

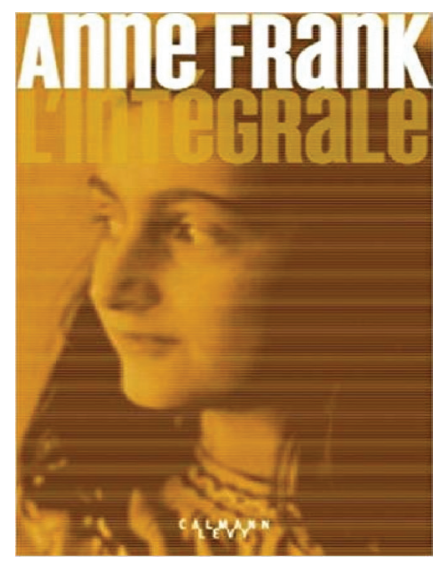

C'est un rêve: tenir entre ses mains les œuvres complètes d'Anne Frank! Il faudrait d'abord pour cela oublier que la moitié du journal original est perdue (un ou deux cahiers ont disparu le 4 août 1944 lors de l'arrestation des habitants de l'Annexe), et que la réécriture sur feuilles volantes entamée par Anne le 20 mai 1944 est restée inachevée. Fondre ces deux versions à la fois incomplètes et imparfaites, c'est la mission que s'était donnée le père d'Anne, Otto Frank. En publiant en 1947 L'Annexe, 
il a réussi à produire le chef-d'œuvre que l'on connaît, mais sa brève préface ne disait rien de cette élaboration complexe et de cette collaboration posthume. À sa mort en 1980, Otto Frank a légué les manuscrits à l'Institut national néerlandais pour la documentation de guerre qui en a publié en 1986 une remarquable édition génétique, sous la signature de David Barnouw et de Gerrold van der Stroom. Cette édition, traduite en français en 1989 (Les Journaux d'Anne Frank), établit l'authenticité des manuscrits d'Anne Frank, que des négationnistes avaient mise en doute, et par un dispositif astucieux permet de suivre page à page le travail des deux écrivains: Anne, passant du texte original de son journal (version a) à une réécriture sur feuilles volantes (version b), et Otto produisant par montage, à partir des versions a et b, le texte publié en 1947 (version c). Sur chaque page, paragraphe par paragraphe, les trois versions (quand elles existent) s'étagent, permettant de comparer, de voir les transformations stylistiques et les recompositions thématiques, et d'identifier qui est responsable des censures (presque toujours Anne, et non son père qui au contraire rétablit souvent des choses qu'elle avait supprimées). En quarante ans, les mœurs ont évolué et le succès mondial autorise la curiosité: en 1991, une nouvelle version (version d1) établie par Mirjam Pressler a élargi le montage d'Otto et donné pleine place à l'aventure amoureuse avec Peter et au discours sur la sexualité. On croyait l'aventure finie quand en 1998 est ressurgie une feuille volante écartée par Otto Frank parce qu'Anne y mettait sévèrement en cause le couple de ses parents (voir La Faute à Rousseau 19 (octobre 1998) 61-64) —d'où une version d2.

La présente édition 'intégrale' ne reprend pas le dispositif comparatif de l'édition de 1986, avec son astucieuse mise en page. Il aurait fallu étager non plus trois, mais quatre versions, ce qui était matériellement impossible. On trouvera donc ici reproduite en tête du volume, pour le plaisir de notre lecture, la version d2 (celle même qu'on peut se procurer en Livre de poche), tandis que les textes originaux d'Anne (le journal et les feuilles volantes, versions a et b) sont refoulés en fin de volume, en annexe, et imprimés en petits caractères à la suite l'un de l'autre. Le véritable perdant de cette mise en page est sans doute Otto Frank dont la version 'revue et augmentée', fondue dans celle de Mirjam Pressler, n'est plus identifiable.

Mais était-il possible d'agir autrement? Il ne s'agissait pas de refaire l'édition critique de 1986, irremplaçable et toujours disponible, mais de donner sous un volume réduit la possibilité de parcourir la vie d'Anne Frank et de faire le tour de son atelier d'écriture. Sur le plan documentaire, de petites lettres familiales, des photos et une série de petites études (la vie d'Anne, l'histoire de sa famille, le contexte historique, la réception 
du journal) donnent d'utiles points de repère. L'essentiel n'est pas là, mais dans deux publications capitales.

La première est la traduction en français du Livre des belles phrases, tenu par Anne de juin 1943 à juillet 1944 sur le conseil de son père. C'est une sorte de journal de lectures, un recueil de citations, lapidaires ou étendues (parfois plusieurs pages), mais sans commentaires. Il a été publié en néerlandais pour la première fois en 2004 (voir La Faute à Rousseau, 37 (octobre 2004) 78). Les goûts d'Anne sont éclectiques, des poésies populaires aux grands auteurs, des classiques néerlandais aux romans pour jeunes filles, et les problèmes abordés vastes et variés, l'amour, la guerre, la misère, le bonheur, le devoir, la mort...

La seconde est la traduction intégrale du 'Livre des petites histoires', recueil commencé à l'été 1943 sous le titre Petites histoires et événements de l'Annexe, décrits par Anne Frank. Il comprend au début surtout des textes autobiographiques (une quinzaine de sketches humoristiques peignant la vie à l'Annexe, qu'elle recyclera en partie dans les Feuilles volantes, et quelques souvenirs de lycée), mais ensuite la fiction domine, un mélange de contes moralisateurs et d'esquisses de romans d'apprentissage, tournant avec Cady au roman psychologique.

Anne prend des notes et fait ses gammes. Tout se joue au mois de mai 1944, elle hésite entre continuer Cady ou se lancer dans l’Annexe: ce sera l'Annexe. Elle a visé juste. On se prend à imaginer ce qu'aurait été sa carrière littéraire si elle et les occupants de l'Annexe avaient survécu. Aurait-elle publié et connu le succès? Vers quelle carrière de romancière était-elle en marche? Peut-être est-ce la mort qui est écrivain? En tout cas c'est à sa lumière que nous lisons désormais l'éclosion de cette œuvre éclatante de vie.

Je ne veux pas, comme la plupart des gens, avoir vécu pour rien. Je veux être utile ou agréable aux gens qui vivent autour de moi et qui ne me connaissent pourtant pas, je veux continuer à vivre, même après ma mort! Et c'est pourquoi je suis si reconnaissante à Dieu de m'avoir donné à la naissance une possibilité de me développer et d'écrire, et donc d'exprimer tout ce qu'il y a en moi! (5 avril 1944, L'Intégrale, 192).

$\mathrm{Au}$ moment même où, pour notre curiosité, est publiée cette édition savante, paraît une édition plus populaire en images. C'est un pari et un pari gagné: il s'agit de condenser le plus fidèlement possible le Journal en un 'roman graphique', à l'intention d'adolescents peu portés sur la lecture. L'image permet d'expliciter de manière pittoresque toute la part subjective du vécu, les émotions, les frustrations, les fantasmes, les rêveries et surtout l'humour d'Anne Frank, qui fait de la vie recluse de ces huit personnes une petite comédie humaine. Mais très habilement les 
deux réalisateurs ont réussi à articuler le jeu des images avec la citation in extenso d'une quinzaine des pages les plus subtiles du Journal où Anne Frank analyse l'éclosion de sa personnalité, juge ses parents, fait écho à sa découverte de la sexualité et de l'amour, réfléchit à la place de la femme dans la société et s'interroge sur son avenir. On ne perd jamais de vue l'écriture du journal ni la progression datée d'entrée en entrée: c'est bien Anne qui est aux commandes, même si son écriture est le plus souvent traduite en images. Une bonne initiation pour adolescents, sans doute, mais peut-être aussi une relecture amusée et émue pour adultes: on n'en finit plus de redécouvrir l'intelligence et la sensibilité d'Anne Frank.

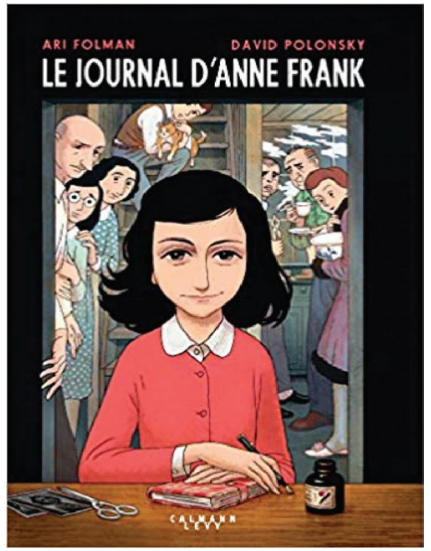

\section{THE FULL ANNE FRANK}

What a dream! To hold in one's hands the complete works of Anne Frank! To imagine such a thing, one first has to forget that half of the original diary is missing (one or two notebooks were lost on August 4, 1944, when the inhabitants of the Secret Annex were arrested), and that the rewritten version on loose sheets that Anne had begun on May 20, 1944, remained incomplete. Putting together these two versions, both incomplete and unfinished, was the task that Anne's father, Otto Frank, took on. When he published The Annex in 1947, he succeeded in producing the masterpiece we know, but his brief preface said nothing about the complications behind it and the posthumous collaboration that had been necessary. When Otto Frank died in 1980, he left the manuscripts to the Dutch National Institute for War, Holocaust and Genocide Studies (NIOD), which published them in a remarkable 'genetic' edition, directed by David Barnouw and Gerrold van der Stroom. This edition, translated 
into English in 1986 (The Diary of Anne Frank: The Critical Edition) and into French in 1989 (Les Journaux d'Anne Frank) demonstrated the authenticity of Anne Frank's manuscripts, which had been challenged by Holocaust negationists, and, through an imaginative presentation, made it possible to follow, page by page, the work of the two writers: Anne, as she moved from the original text of her diary (version a) to a rewriting on loose sheets of paper (version b), and Otto, producing a montage based on versions $\mathrm{a}$ and $\mathrm{b}$, the text published in 1947 (version c). On each page of the 1986 edition, the three versions (when they existed) were printed side by side, making it possible to compare them, to see the stylistic transformations and shifts of thematic emphasis, and to see who was responsible for omissions (almost always Anne, and not her father who, on the contrary, often reinserted things that she had taken out). In the course of forty years, customs had changed and the work's worldwide success authorized curiosity. In 1991, a new version (version d1), put together by Mirjam Pressler, expanded Otto's montage and gave a fuller version of the love affair with Peter and Anne's thoughts about sex. It seemed that the exploration was complete when, in 1998, a loose sheet left out by Otto Frank, in which Anne judged her parents severely, came to light (see $L a$ Faute à Rousseau, 19 (October 1998) 61-64) —resulting in a 'version d2'.

This new 'integral' edition does not reproduce the imaginative arrangement in the 1986 edition. It would have been necessary to put not just three, but four versions side by side, which was not a practical possibility. What is reproduced in this new edition is, then, first, for our reading pleasure, version d2 (the one now available in paperback editions), followed, at the end of the volume, Anne's original texts (the notebooks and the loose sheets, versions a and b), printed in small type, one after the other. What is lost in this arrangement is, without any doubt, Otto Frank, whose 'edited and enlarged' version, merged with that of Mirjam Pressler, is no longer identifiable.

Was any other solution possible? It was not a matter of redoing the critical edition of 1986, irreplaceable and still available, but to produce something small that would offer the possibility of following Anne Frank's life and understanding how she produced her work. On the documentary level, some short family letters, photographs, and a series of small studies (Anne's life, the story of her family, the historical context, the reception of the Diary) provide useful information. What is most important, however, involves two important new publications.

The first is the translation into French of the Book of Elegant Passages that Anne composed between June 1943 and July 1944, at the urging of her father. It is a sort of diary of readings, a collection of quotations, brief or extended-some run to several pages—but without any commentary. 
It was published in Dutch for the first time in 2004 (see La Faute à Rousseau, 37 (October 2004) 78). Anne's taste was eclectic, from popular poetry to great authors, from Dutch classics to novels for young girls, and the topics evoked are vast and varied: love, war, suffering, happiness, duty, death...

The second is the complete translation of the Tales from the Secret Annex, a collection started in the summer of 1943 under the title of Little stories and happenings in the Annex, described by Anne Frank. At first, it consists above all of autobiographical texts-some fifteen humorous sketches depicting the life of the Annex, which she reused in part in the loose-sheet version of the Diary, and some memories of school life-but later fiction became dominant, with a mixture of moral tales and sketches for novels about growing up, turning with Cady toward the psychological novel. (English translations of the 'Tales from the Secret Annex' and 'Cady's Life' are included in The Diary of Anne Frank: The Revised Critical Edition (2003).

Anne takes notes and practices her exercises. A crucial point is reached in May 1944: she is not sure whether to go on with Cady or to start on The Annex, the revised version of her diary. She makes the right choice: The Annex. One finds oneself imagining what her literary career might have been like if she and the other occupants of the Annex had survived. Would she have published and been successful? What kind of novelist's career was she headed toward? Perhaps it was death that made her a writer? In any case, it is in the shadow of her death that we now read the emergence of this work, so full of life.

At the same time as this scholarly edition has been published to satisfy our curiosity about the original text of the diary, an edition in images, aimed at a more popular audience, has also appeared. It is a challenge successfully met: to be as faithful to the Diary as possible while making a 'graphic novel'. Published in English as Anne Frank's Diary: The Graphic Adaptation (Pantheon Graphic Library) and in French, the images offer a pictorial means of showing the subjective aspect of the author's experience: the emotions, the frustrations, the imaginings, the dreams and, above all, the humor of Anne Frank, who made the life in hiding of the eight people she described into a small-scale Balzacian 'human comedy'. The two collaborators have skillfully succeeded in combining the sequence of images with extended reproductions of fifteen of the most subtle pages of the Diary, in which Anne Frank analyzes the growth of her personality, judges her parents, describes her discovery of sexuality and love, reflects on woman's place in society, and ponders her own future. The writing of the journal and the temporal progression from entry to entry are never obscured: Anne remains in charge, even if her text is mostly converted into pictures. A good entry point into the text for 
adolescents, to be sure, but also, perhaps, an amusing and moving way for adults to reread it and discover, once again, the intelligence and sensitivity of Anne Frank.

Translation from the French by Jeremy Popkin

\section{NOTE}

1 Cette critique a été publiée pour la première fois dans la Faute à Rousseau, revue de l'autobiographie, 77, (février 2018) 58-60.

This review was first published in la Faute à Rousseau, revue de l'autobiographie, 77 (February 2018) 58-60. 